\title{
Religiosity and Social Capital as Prevention of Socio-Pathological Phenomena
}

\section{T. Bak (Tadeusz Bak) ${ }^{1}$, K. Kardis (Kamil Kardis)²}

Professor at the University of Presov in Presov, Slovakia.

\section{E-mail address:}

kamil.kardis@unipo.sk

\section{Reprint address:}

Kamil Kardis

University of Presov in Presov

08001 Presov

Slovakia

Source: Clinical Social Work and Health Intervention

\section{Reviewers:}

Selvaraj Subramanian

SAAaRMM, Kuala Lumpur, Malaysia

Pawel Czarnecki

Rector of the Warsaw Management University, Poland

\section{Keywords:}

Religiosity. Socio-Pathological Phenomena. Cultural Crisis. Desocialization.

\section{Publisher:}

International Society of Applied Preventive Medicine i-gap

CSWHI 2020; 11(4): 51 - 56; DOI: 10.22359/cswhi_11_4_07 (C) Clinical Social Work and Health Intervention

\section{Abstract:}

According to M. Fforde, the era of postmodernity is characterized by a form of cultural collapse as it reveals many phenomena indicating that human in contemporary society is directed towards "desocialization." This process represents an overall cultural shift as well as a change in the models of human. These are the main factors of the cultural crisis (Kuna, 2006). This paper is dedicated to an analysis of the issue of religion as social capital in conditions of increasing societal risks. We work with an hypothesis that socio-pathological phenomena are rather determined by cultural and secularization factors. 


\section{Theoretical view: \\ Context of a postmodern world}

The Authors in the paper: Suicide and Society: The Sociological Approach (2019) presented social context of the second demographic transition which has brought profound changes in value orientations and moral attitudes of today's society. In the microspace of an individual it has become increasingly difficult to create one's own identity; answer fundamental existential questions; or create a meaningful horizontal and vertical world of relationships and a coherent support system. Instead of an individual's identity being formed in the process of primary and secondary socialization, it is often deformed, having been influenced by de-socialization of family, school or peer environments. Mesospace of community life has also suffered consequences caused by the lost community (Gemeinschaft) and modernization processes of the industrial and post-industrial society. Fforde describes the concrete manifestations of desocialization in his book Desocialisation: The crisis of Post Modernity using the example of the British society. However, it is important to emphasize that British society is already subject to globalization and universalization in the European socio-cultural space. In concrete terms, desocialization involves a conflict between anthropologies. The facts that man is anchored in transcendence, and that a negation of transcendence in his life has condemned him to a life of emptiness and absolute vanity, are not taken into consideration. Fforde speaks about the false anthropologies that do not recognize the soul within man but accept a model of ,material matrix" to describe man. It means that the model of man as created by God, who infuses a soul to him, or what corresponds to a so-called ,spiritual“ model, is constantly denied. The material matrix acts against the community by supporting a lifestyle of selfish individualism and thus weakens the relations between people. The breakdown of ties between people is clearly demonstrated by cultural breakdown: the decay of good manners in politic life; the increase in people living alone; the low electoral turnouts; the high levels of crime and violence; and family crisis (Fforde, 2010) ${ }^{1}$.
As some authors comment, ,,...) the negative evolutionary influences of the Western European culture will now be exported, among other countries, to Slovakia as well. There follows his (M. Fforde's) argument. The contemporary Western culture is characterized by the expansion of phenomena such as secularization and dechristianization as well as by the dominance of the materialistic view of man. These views have not only replaced Christian understanding of man but they also represent the natural matrix and have a tendency to create convincing but deformed opinions about who we are by choosing one aspect of our self and enhancing it to the level of the superior truth concerning who we are and what we do. The introduced material matrix stimulates selfish individualism; the breakdown of community; consequently, people find themselves in the state of loneliness and isolation. Therefore the material matrix is the main cause of this state - desocialization. This evolution is very negative since desocialization is closely connected with lack of happiness and with mental unease on a large scale. One of its practical consequences will be an increase in the number of people suffering from various psychological problems. These contribute to lower quality of life. However, paradoxically, this problem is not solved by elimination of its roots but by prescribing some anti-depressants. This is only one of the examples of how people try to escape their suffering by recourse to varied therapies which make their illness even worse."

M. Fforde believes that Western materialism will lead to an export of desocialization to Central Europe. He sees this as a serious threat. He also claims that Slovakia is now in the process of rising exposure to the dynamics of Western culture. The process of globalization and European Union membership contribute significantly to this situation. He also speaks about the risks in the admiration and the uncritical approach adopted by the post-communist countries to the penetration of western culture as demonstrated by an almost automatic adoption of Western lifestyle and values. He adds that after the devastating effects of Communism, Slovakia has to

${ }^{1}$ Matthew Fforde, Western Materialism and the Exportation of Desocialization, 23-25. 
face further challenges concerning Christianity and society ${ }^{2}$. Slovakia was involved with materialistic and anti-Christian ideologies until 1989, and in the same year, it was brought face to face with the Western form of consumer materialism and laicism. However, both forms have a common basis - the reproductive interpretation of man - a rejection of transcendence that is antihuman. According to M. Fula, from the ideological point of view, Slovakia does not face a completely new challenge because it already experienced a fight for man's soul during the Communist regime. It can profit from this fight when dealing with the penetration of Western materialism $^{3}$. It must be emphasized, however, that while Slovakia is involved in the cultural crisis of Western countries, its dynamics are qualitatively and quantitatively different. Consequently, the origins of the crisis under scrutiny are identical in the whole Europe.

The issue of desocialization is a general problem extending over all social, ethic, political and religious domains. The spread of desocialization cannot be stopped, but our aim is to outline some characteristics of the phenomenon to help people become immune to it. Desocialization of society must be primarily dealt with within the scope of religion and Christianization - the spreading of Christianity ${ }^{4}$.

In the context of the above facts, it is clear that the egoistic emphasizing of the individual's importance has become a prevailing lifestyle. Too much importance is attached to economic wealth, powerful positions, social prestige and delights. These determinants are closely connected with a searching for individual benefits which logically contradict the existence of the authentic collectiveness. We live in a modern, rushed and over-technological era where the decisive factors of man's success are to be the best, the first and the only, all at the same time. We want success at any price. However we do not bother about the consequences of this „track.“ We proceed in the community with no regard for other people; without respect for generally accepted rules, social conventions and especially fundamental ethic and moral rules. Thus we exclude ourselves from society as such and do not want to perceive its seriousness. We put ourselves on its periphery, its boundary and so we contribute to desocialization of the present time.

One of today's major issues is the question of whether post-modern Europe is undergoing a serious social crisis. This issue is illustrated by undesirable facts such as overconsumption; decay of family; individualistic materialism; relativism of values; loss of interest in public matters. There is another connected question: Are these facts the consequence or the cause of the universal decline of Christian religiosity in Europe, as well as in Slovakia? This thesis is dealt with in detail by M. Babic who adopted a critical approach focusing on the essay written by above mentioned $\mathrm{M}$. Fforde. On the one hand, his article is an analysis of all the phenomena concerning the decline of postmodern society. On the other, as a cultural historian, he tries to point out multiple similarities between the civilizations of the past and the present.

Desocialization is therefore closely connected with secularization processes, as well as with the progression of secularization and a materialistic view of man according to the models and theories of postmodern anthropologies. These trends are demonstrated by the retreat of the individual, with his misguided and often materialistic goals, from the real community to his own egoistic and over-individualistic world. In concrete terms, this corresponds to the relativistic understanding of truth; the consumerist approach to love; the instability of alternative forms of collective life; the escape from social responsibility in political parties and other organizations; the decay of family; the increase in the number of singles; the spreading of mistrust among citizens; the state of depression; the prevalent violence; the high levels of crime (Tomko, 2006).

\footnotetext{
${ }^{2}$ Matthew Fforde, Western Materialism and the Exportation of Desocialization, 257, 264.

${ }^{3}$ Milan Fula, The anthropological stimuli to solve the crisis of the West, In Slovakia, materialism and desocialization, 196-197.

${ }^{4}$ Jan Duda, What will stop the desacralization in Slovakia In Slovakia, materialism, and desacralization, 227228.
} 


\section{Religiosity as an anthropological constant in the context of post-modern culture crisis.}

According to Marian Mraz's (Mraz, 2014) concept, religiosity represents a basic cognitive and axiological component of social reality (Voegelin, Berger, Luckmann). It is the discovery of the meaning of life and universe that goes beyond the secularly specified borders. Religiosity is a particularly significant habitual attribute of man as an individual; it is a principal element contributing to culture. It serves as a foundation for thinking about the meaning of life of an individual and the society. It draws from the sapientiality of man - i.e. from his reason. Wisdom sapientia - is an adaptation ability which is responsible for spiritual and cultural dimensions in biosphere - anthroposphere and noosphere. Wisdom - sapientia is closely related to another anthropological constant, religiosity. Drawing on Durkheim's postulate of religiosity as anthropological constant, Voegelin defines it as something inherent in man, something he cannot, get rid of". Boyer regards religiosity as ,natural human ability" and a new attribute of our standard cognitive abilities. Therefore, it is possible to perceive religiosity as an anthropological constant and any science or social and political project ought to take it into consideration and address it. Man has ambitions of the Absolute and thus his essential desire for happiness and a vision of panhuman unity cannot be boxed up in the world of secular limitations.

It is beyond doubt that religion is a universal phenomenon. Efforts to replace it with positive science or to destroy it using political means have failed. Postmodern era has discovered horror vacui - fear of empty spaces, nothingness and absurdity that cannot be driven away either by the entertainment industry or the cult of hedonism (Mraz, 2014). Rejected religiosity has suddenly become a subject of interest for the ideologists of postmodernism. For Luckmann and Berger, religiositas means a symbolic universe as a basic cognitive and value framework of social reality. They assume that the religious elements in today's society are present in our way of thinking, especially when assigning a more profound meaning to our actions and life in general. (Berger, Luckmann 2010).

Scientific research into a phenomenon of religion was initiated by a leading French sociolo- gist Émile Durkheim. Religion is an objective social fact, a universal phenomenon resulting from the very essence of social reality. In his book, The Elementary Forms of Religious Life, Durkheim defines religion as a unified system of beliefs and practices relative to sacred things, that is to say, things set apart and forbidden; a system of beliefs and practices which unite all those who adhere to them into a single moral community called Church.

Durkheim stresses an integrative function of religion. Religion is, therefore, and expression of our collective consciousness and images of society. It is an important determinant that ensures integrity of the society by strengthening collective consciousness and thus preventing anomie.

In his work, Max Weber, a creator of interpretative sociology, analyses impact of religious ideas on economic structures of the society. Religion as a means of human rationality determines life practice and it is a force behind social transformations.

Thomas O'Dea, supporter of a functionalist theory of religion, advocates a basic proposition stating that the social system tries to maintain a balance of those social institutions whose purpose is to regulate human actions. Religion is one of the elementary forms of institutionalized social action whose main goal is to partake in maintaining the stability of the whole system.

O'Dea was concerned with a question encompassing three dimensions - social system, culture and personality. He wanted to determine what functions religious institutions have in maintaining the stability of social system, personality and culture as a whole. O'Dea listed six basic functions of religion in the society with the focus on two goals. Religion provides an orientation for something outside the world of empirical experience and ordinary everyday life. It allows an individual to experience and overcome the feeling of deprivation and frustration that today's world bring with respect to this transcendent reality beyond the empirical. The second goal is to provide some sense of safety and security through participation in rituals that connect man with the supernatural world. The six functions are:

- religion provides support, consolidation and comfort in an insecure world;

- through cult and ceremonies it provides tran- 
scendent relationship and by doing so it is instrumental in finding a sense of security. It helps an individual to find his place in the world. Religion contributes to stability and helps maintain the necessary order, not only social but also ontological;

- religion sacralises norms and values of society, it prefers group goals to individual desires;

- religion can provide values that challenge the established norms and hereby support the change of an existing social order;

- religion helps to form and maintain identity;

- religion facilitates transition from one age group into another.

Milton Yinger, supporter of a functionalist concept of religion, attempted to set forth a definition of religion in a broader sense of this phenomenon. He proposes that any social phenomenon can be identified as "religious" if it helps an individual to deal with and explain death, suffering, evil and injustice. Yinger claims that religion is a system of beliefs and practices by means of which a group of people deals with existential problems of human life. Yinger sees religion as a dynamic phenomenon changing over time, a phenomenon which satisfies specific needs within a social system.

Thomas Luckmann maintains a similar stance on religion and its status in modern society. $\mathrm{He}$ sees religion as an ability of human beings to transcend their biological nature. Man is the only creature able to construct a world of objective and ontological meanings that present morally binding and all-encompassing reality. For Luckmann, therefore, religion is not only a sociocultural but also an anthropological phenomenon. Everything that is tout court human is ipso facto religious. On the other hand, unreligious phenomena are those that originate in animal nature of a man, in his biological constitution common with animals. (Luckmann 1967: 25; Berger 1971a: 268-271).

Today, even materialistic socio-biology begins to perceive religiosity as ,,a genetically preconditioned attribute of human psyche" (Remes, 2003). Translated into the language of today's anthropology, religiosity is an extraordinary anthropological constant, a habitual trait of an individual and an essential element contributing to the formation of culture.

Pascal Boyer teaches classes in psychology and anthropology at Washington University in St.
Louis. Although he draws from a materialist conviction that the entire human thinking results from the structure and processes of our brain, his view on spirituality and religiosity is more or less undermined by his claims that brain ,naturally guides our morality and social relationships“. He backs his statement with the theory of evolutionary origin of religious thinking. In the course of human development, religiosity has enabled man to cultivate and maintain large coalitions of not related individuals and build a mutual trust based on criteria of reliability. Boyer (2011) regards religiosity as a „natural human ability“ and a new attribute of our standard cognitive abilities. Unbelief in the supernatural is, to a certain extent, a result of our development against our innate cognitive predispositions. Religiosity is closely linked to a development of one's sociability, it forces man to stay vigilant for any dangers and prevent risks, and inculcate an intuitive adherence to social norms found within particular ethos. Contemporary social science, too, highlights the role of religion in cultural reinforcement of solidarity and cooperation within a particular group. In contemporary religious systems, sacred books and traditions can be seen as inspirational sources for social support (Szot, 2010a).

According to the concepts of religious prosociality, religions support action that is intended to benefit other people, although it might cause harm to the doer. Sacred texts of all big religions explicitly command people to be prosocial. Another common trait is a therapeutic dimension of religiosity.

The rediscovery of religiosity might have come as a shock to some reductionist postmodern sciences. Yet it has long been an established fact for therapists that authentic religious faith conceals mysterious and surprising possibilities: it transcends; allows man go beyond limitations of space and time; even beyond the limits of biological life; brings essential anthropological optimism; releases in man powers and energies one could have only assumed. There have been cases of many evident and yet mysterious occurrences, be it spontaneous or medically inexplicable cures, surely linked to spiritual powers in condition humana - in the structure of human being we do not know yet. In this new light, religiosity is again introduced to man as a specific power which is not only a key value in his value system, 
but it can also serve as a source of meaning of one's life, his physical and mental wellbeing. And here we arrive at the very essence of our existential desire for immortality. In this context, current sociology of religion shows religion, as a central cultural and social phenomenon having an important role mainly in relation to borderline situations or turning points in the lives of individuals and the whole society. On one hand, man lives in conditions of insecurity, coincidence and being aware of one's own weakness, he experiences situations outside his anticipation and control. On the other hand, man lives in society with prevailing individualism, differentiation, consumerism, value relativism, and axiological chaos and that all can result in alienation, frustration and loss of identity. Finding ourselves in these situations can lead to existential problems we all desire to find answers to. It is religion that offers that answer because it transcends everyday empirical experience and transfers problems to the realm of sacrum, offering a sense of security, safety and support (Adamski, 2011, p.5).

\section{References:}

1. BAK T (2010) The youth in the context of new religious - moral reality In New religious movements, sects and alternative spirituality in the context of postmodernity. Ed. by K. Kardis, M. Kardis Presov: GTF PU, 2010, 157-163.

2. BERGER P (2008) Religion and the global civic society. In Religion in the global civic society. Ed. by J. Hanuš, J. Vybiral. Brno, 2008, 9-22.

3. CHRISTIAN CHURCHES IN POST-COMMUNIST SLOVAKIA: CURRENT CHALLENGES AND OPPORTUNITIES (2012) Salem : Center for religion and society, Roanoke college, 2012.

4. FFORDE M (2010) Desocialization. A post modern crisis. Bratislava: Luc, 2010.

5. FUKUYAMA F (2006) The big disruption: human nature and the reconstruction of social order. Praha: Academia, 2006.

6. GIDDENS A (2006) The framework of late modernity. In Contemporary sociological theories, vol. 2. Ed. A. Jasinska-Kania and group. Warszawa: Scholar, 2006, 687-699.

7. GIDDENS A (2010) The consequences of modernity. Praha: Slon, 2010.
8. HALIK T (2008) Religion in its relationship to civic society and truth. In Religion in the global civic society Ed. J. Hanus, J. Vybiral. Brno: CDK, 2008, 95-107.

9. HARRINGTON A (2006) The modern social theories. Praha: Portal, 2006.

10. INGLEHART R, NORRIS P(2006) The Sacred and the Profane: Religion and politics in the world. Krakow: Nomos, 2006.

11. JOHN PAUL II (2018) Ecclesia in Europa. [online]. http://www.kbs.sk/print.php? cid= 1117289696 (07.12.2018).

12. KARDIS M (2008) The dignity of human being as a subject of international economic relations. In Man, borders of rule, economy. Ed. by T.Guz, K.A.Klosinski, P.Marzec, Lublin: Wydawnictwo KUL, 2008, 45-58.

13. LUZNY D (2005) The Individualisation and modernization of religion In Modern religion. Bratislava: 2005, 239-253.

14. LUZNY D (2005) Order and power. Selected texts from the sociology of religions. Brno: Masaryk University, 2005.

15. MARIANSKI J (2006) The secularisation and desecularisation in today's world. Lublin: Ed. KUL, 2006.

16. NESPOR Z, LUZNY D (2007) Sociology of religions. Praha: Portal, 2007. Pace, Enzo. The movements of renewal and rebirth. In Encyclopaedia of world religions, Vol. 2. Ed. by F. Lenoir, Warszawa: Dialog, 2002, 24052415.

17. PIWOWARSKI W (1996) Sociology of religion. Lublin: RW KUL, 1996.

18. SZTOMPKA P (2009) The sociology. Warszawa: Znak, 2009.

19. SUBRT J at al. (2007) The present sociology I. Theoretic concepts and their authors. Praha: Karolinum, 2007.

20. TIZIK M (2006) To the sociology of new religiousness. Bratislava: Komensky University, 2006. 